\title{
Germany: Myth and Apologia in Christa Wolf's Novel Medea. Voices
}

\section{Yixu Lü, Institute for International Studies, University of Technology Sydney}

To understand the background to this recasting of the familiar Greek myth as a novel narrated by several voices, a few bare details are necessary. In 1984, Christa Wolf produced her first re-casting of an ancient myth with the title Kassandra. Published at a time when West German interest in East German literature was at its height, Kassandra became a cult book in the West without obliging its author to flee the East or having her silenced by the censor-no mean achievement. Kassandra skilfully blended the type of feminism then popular in the West with a somewhat elegiac depiction of the betrayal of ideals in a society falling prey to totalitarianism. A contributing factor to the book's success was the simultaneous appearance of a series of lectures the author gave at the University of Frankfurt, in the Federal Republic, in which she set forth very eloquently the background reading and conceptualisation which led to the form Kassandra finally assumed. There were critics who felt that the lectures, giving the novel's 'presuppositions', were generally better written than the work itself, since they give the overall effect of an openness which is lacking in the highly stylised and gloomy prose of the novel itself.

In 1989, Christa Wolf, as one of the mildly dissident public identities still tolerated by the East German regime, was ideally placed to speak for those who wanted the crumbling of the old East Germany to make the way free for a genuine experiment with socialism, in whose values she still fervently believed. Her voice, initially prominent in the internal political process leading up to the first free elections in the German Democratic Republic, ceased to be effective once it became clear that the overwhelming majority of her fellow citizens rejected the path she and other intellectuals advocated in favour of an immediate union with West Germany.

In 1990, Christa Wolf published a manuscript whose title translates as What Remains. In it she recalls a period in which she became the object of surveillance by the Secret Police, thus allying herself implicitly with those dissidents who had been virtually forced into emigration through harassment by the Stasi. This did not sit altogether 
well with the reading public of a united Germany, since she had, in fact, also achieved a modus vivendi with the communist regime over several decades while her works were enjoying great success in the West, and it seemed opportunistic for her now to claim something of the status of those whose existence the Stasi had rendered impossible to the point where they were, in effect, pushed into unwilling exile.

The major blow to Christa Wolf's literary standing was the publication in 1993 of the dossier kept on her by the Stasi. From this it became evident that, whilst she had never carried out spying activities for them, she had in the early ' 60 s signed an agreement that she would, if required, become one of their 'unofficial collaborators'. Her own political situation had been very different then, and the media and public might have been prepared to forgive and forget, had she not already created a climate of irritation among her past and present readers by the claims to victim-status advanced in What Remains.

What followed was a process of 'scape-goating'; the former eminent East German writer who could remain there and publish, whilst enjoying the status of a highly respected literary figure in the West, became for many an example of the re-writing of their own biographies by formerly prominent East Germans in order to be respectable in the 'new', united Germany. Unfortunately for Christa Wolf, she had been caught out—or so it appeared.

Behind the 'scape-goating' there was the more general consideration of the treatment of East German literature by West German critics for as long as the Berlin Wall remained in place. In general, the West German reception of East German writing was more charitable and less stringently critical than the quality of the works themselves may have justified - for purely political reasons. Christa Wolf had been one of the major beneficiaries of this process in two senses: firstly, her works had generated a critical industry in the West that made of her a leading literary figure across the two Germanies; secondly, her eminence in the West meant that the regime's treatment of her works in the East, while at times the object of savage polemics on the part of 'orthodox' critics, was much more tolerant than if she had been a young writer starting out or a dissident who had entirely failed to interest the West German media. 
Her fall from grace was therefore also pre-programmed in a sense. Given the freedoms she had enjoyed in what she wrote while the Berlin Wall still stood, many former East German writers took against her. Her Western colleagues and critics were also prompt to come to the conclusion that there had been a general over-estimation of her quality as a writer. Against this unfolding personal drama, her version of Medea took shape between 1991 and 1996.

Looking back on the gestation of the work in 1997, Christa Wolf reviews the process of revaluation and remodeling to which she subjected the myth:

Like all those I asked, I was acquainted with Medea as Euripides represents her: the barbarian woman from the East who, inflamed with love for the Argonaut Jason, helps him to steal the Golden Fleece. For this reason he has come to her native Colchis on the Black Sea, the easternmost fringe of the world then known to all Mediterranean peoples. She flees with him and, after various wanderings, lands in Corinth, the westernmost point of the Mediterranean world. There Jason turns away from her and wishes to marry the daughter of King Creon. Medea is exiled from the city. But in Euripides' version she is so demented by jealousy and outraged pride that she first kills Creon's daughter and then her own children.

I could not believe this. A healer, a skilled practitioner of magic-for so she must have been in the most ancient strata of the myth which stem from times when children were the most valued property of a tribe and when mothers were highly esteemed precisely because they guaranteed the tribe's continuance - such a one should murder her own children? (Hochgeschurz 1998, p. 15)

In the following paper, I shall try to demonstrate what steps Christa Wolf undertook in recasting a myth she clearly found repugnant in its best-known literary version. In doing so, I shall be constantly subjecting the ideology behind her adaptation to critical scrutiny. From the above, there is no doubt that she intends a rehabilitation of the mythical heroine. In testing its effectiveness, I shall be posing the question: does Wolf's 'acquittal of Medea' - as another modern German revamping of the myth by Ursula Haas (1987) is styled - go no further than a reversal of 'patriarchal' mythmaking, or does she have more sophisticated intensions?

To make the subsequent analysis intelligible, it is necessary to list the basic changes in the plot from the version we know through an acquaintance with Euripides. To begin with, Christa Wolf's Medea does not kill her own children. Rather, once she is sentenced to leave Corinth, she entrusts them to priestesses in the sanctuary of Hera. No sooner has she quit the city than they are taken from the sanctuary by a mob and put to death (Wolf 1999, p. 217). Nor does Medea murder her brother Apsyrtos. In Wolf's version he is killed at the command of their own father, Aietes, before the 
Argonauts flee Colchis and as a result of a piece of despicable local politics. Wolf then goes on to expunge many of the supernatural elements: Medea has no divine ancestry and does not leave Corinth after the murders in a chariot drawn by winged serpents. Her turning against her own father is no longer motivated by her falling passionately in love with Jason - a passion which some pre-Euripidean versions have as the result of divine intervention- but Jason becomes a pretext for her to flee Colchis after an attempt to end the reign of Aietes, in which she herself is involved, has ended in failure. Medea is likewise quite innocent of the death of Creon's daughter Glauké, a pitiable epileptic who drowns herself in a well in her father's palace. Finally, Medea, rather than being fixated on Jason to the end, frees herself of any attachment to him and finds satisfaction in a new love for the sculptor Oistros, who is entirely Christa Wolf's invention, as the name implies.

Thus we have, in summary, a tragic heroine who kills no one; a witch who only uses her powers for healing; a daughter who has connived at the theft of the her father's Golden Fleece for the best of political motives. It is thus that the suspicion of a 'Medea for Feminists' may arise, for Christa Wolf's version of the figure has not only forfeited all those actions and attributes that would define her out of the sphere of leftist-liberal respectability at the close of the $20^{\text {th }}$ century-she has also acquired so many wholesome and well-meaning traits as to appear at times a deliberate incarnation of trendy, feminist virtues.

Since Wolf has stripped away so many mythical traditions and turned others upside down, we must ask what are the wellsprings of action in her re-telling. Medea remains the quintessential 'stranger' - the outsider figure both in her native Colchis and in Corinth. This means the abolition of the distinction so natural to the Greek tragedian Euripides between culture and barbarism, for in Wolf's version both Colchis and Corinth are corrupt societies, equally dominated by dishonest patriarchal regimes and both based on the public denial of their own inhumanity, exemplified in each case by human sacrifice. In Colchis, Medea's brother Apsyrtos, is ritually slaughtered as a stratagem to allow his father Aietes to have yet another reign as 'sacred king'. In Corinth, Medea makes the discovery that the elder daughter of Creon and Merope, Iphinoe, has been sacrificed in secret as part of a plot to assure Creon's dominance in 
a power-struggle with his own queen. The Greeks who wield power are, if anything, more barbaric than the barbarians.

It is precisely in the monologue of Akamas, the most unscrupulous power-broker among Creon's advisers, that the brutality of the killing of Iphinoe is highlighted:

Where are we going, Iphinoe is said to have asked at one point; her nurse patted her hand to calm her; what are they doing? Iphinoe asked at the very end, when someone seized her by the nape of the neck and bent her head down upon the altar [...]. The nurse kept holding her hand which twitched as the knife went into her throat. [...] Of course, the nurse went insane, [...] running all day through the streets of Corinth surrounded by guards to prevent anyone from talking to her. She avoided the queen; one day her shattered body was found at the foot of the sea-cliffs. (Wolf 1999, p. 120)

Christa Wolf has thus made the dominant contrast in her version of the ancient world, not the usual one between Colchis and Corinth, between culture and barbarism, but one between an inhumane patriarchy and a more compassionate matriarchy, an opposition she had already explored in her lectures on Kassandra some years before.

The cynical statesman Akamas freely admits that, in the past, kings derived their right to rule from their queens, but then goes on to quote Creon's rationalisation of the suppression of women as a political force in the name of expediency and historical processes:

Not selfishness, but rather his concern for the future of Corinth had set him on this course. For anyone who could read the signs of the times could see that, with all the wars and atrocities around us, states were being formed among which a Corinth based on the old way of doing things, when power was in the hands of women, would simply not be able to sustain itself. And it was pointless to set oneself in opposition to the march of history. The best one could do was to try and recognize its direction before it was too late-otherwise one would simply be overrun. Admittedly the price one might have to pay for acting opportunely could be very painful. (Wolf 1999, p. 116)

A constant undercurrent of resentment at the object-status women inevitably acquire in this scheme of things runs through the whole novel. It is epitomised in the traumatic moment in Medea's first monologue when she recounts the discovery of the remains of the sacrificed Iphinoe, by following Creon's wife into the subterranean passages beneath the palace in which a feast is being celebrated. Medea's 'otherness' always contains within itself an ingredient of anxiety at herself being treated as a mere object. Christa Wolf's introduction of a new figure into the complex, the woman from Colchis, Agameda, who begins as Medea's apprentice-healer but soon supplants her because she adapts better to the plots and expectations of the men of Corinth, highlights this loss of autonomy. In the versions of Euripides and Seneca, Medea's 
status as a tragic heroine is linked to her being genuinely dangerous, whereas in Wolf's rewriting she runs the risk of being merely an irritant, an annoyance.

Medea remains herself essentially by refusing to do what is expected of her. Having left Colchis with the ideal of finding a better society than that ruled by her own corrupt father, a society without gruesome 'secrets' (Wolf 1999, p. 16), she is reduced by the sameness she finds in Corinth to more or less trivial acts of 'subversion' or passive aggression. This effect is also reinforced by the structure of the novel. Those 'voices' not actively hostile to Medea, like Agameda, or condescending, like Akamas, are either confused victims themselves, like the unfortunate Glauké, or resigned spectators, such as the astronomer Leukon.

Thus it follows that Medea's own final monologue expresses total resignation. Living in isolation in the mountains with Lyssa, her own Colchian nurse and the nurse of her children, she is shocked by the news that her sons by Jason, whom she believed to be protected in Hera's sanctuary, are long dead, the victims of mob violence, and that the Corinthians have fabricated the lie that she herself has killed them and then institutionalised this calumny in an annual ritual. Her last utterance in the novel is a curse whose powerlessness is clear to herself:

\footnotetext{
What is left to me. To curse them. A curse on you all. Especially a curse on you: Akamas. Creon. Agameda. Presbon. May your lives turn to horror and your deaths be wretched. Your howls shall go up to Heaven and Heaven shall not be moved. I, Medea, curse you.

Where shall I go. Is there a world, a time in which I would be at home. No one here to ask. That is the answer. (Wolf 1999, p. 218)
}

What we therefore have in Christa Wolf's version is not merely a Medea purified of all the malice, rage and power that have made her an archetypical 'fury', but one who seems to be the vehicle of various ideological intentions that bind her to a series of contemporary discourses. It is now time to enquire into these.

It has been clear since the publication of her notes for Kassandra, written down in the early ' 80 s, that Christa Wolf sees her re-working of myths with full seriousness a process of restoring a distorted historical reality. Myths are for her anything but flights of creative fancy or intense passions in narrative disguise. Rather they are 'a complex but still decipherable intellectual processing of enormous historical 
processes in distant antiquity, a grandiose form of mirroring the transformation of hordes of hunter-gatherers via agrarian tribes into hierarchically structured city states with their own distinctive magical world-views' (Hochgeschurz 1998, p. 14). It is for her a fact that in Ancient Greece a matriarchal society preceded one ruled by men. Such 'facts' have been distorted and obscured because men got to warp them with the help of the 'patriarchal' literary form of epic poetry:

The epic, a form that owes its origins to the time when patriarchal rule struggled to establish itself, becomes by its very structure an instrument for making this dominance more elaborate and secure. [...] As a heroine, woman can be but the object of masculine narrative: Helen of Troy, who survives in the myths as a petrified idol, being a case in point. (Wolf 1983, p. 147)

This does not necessarily descend to being a conspiracy-theory of myth-making as male propaganda, but Christa Wolf intends her readers to recognise, through the medium of her restorative reconstructions that 'always the same motives are active in getting one group of people to devalue and demonise another: ignorance, fear, the desire to keep the other at a distance, feelings of guilt, the need to feel exculpated' (Hochgeschurz 1998, p. 23).

A case in point in the text of her Medea are the Colchians who, having willingly come to Corinth in search of a better society, now blame the woman they followed for their disappointment, and clothe this in nostalgic stories of the place they were so eager to leave:

Their legends [of Colchis] will get more and more out of hand as our situation gets progressively worse, and there is no point in confronting them with the facts-even if there are such things as facts after so many years. (Wolf 1999, p. 31)

Jason, too, shows an awareness of the manner in which his own narratives of gaining the Golden Fleece shift in the telling so that his first-person account becomes partly a function of the audience's expectations:

I have been obliged many times to tell how I climbed the tree, how I got hold of the Fleece and managed to get down again with it safely, and each time the story changed a little in the telling, just as each audience wanted it to go, so that they could work themselves up into a real state of fright and feel really relieved at the end. It has got to the point that I no longer know myself exactly what I did go through in that grove with the oak-tree and that serpent, but no one is in the slightest interested in hearing that. [...] In the end she [Medea] said: they have made of each one of us what they need: out of you the hero, out of me the evil woman. They have driven us apart. (Wolf 1999, p. 52)

Thus Christa Wolf's recasting of the myth is, at the same time, an illustration of how myths come to assume the form in which we know them. The problem remains that 
her demonstrations of the phenomenon are not ideologically neutral, but, as she freely admits, are governed by the tradition which begins with Bachofen, then continues with The White Goddess by Robert Graves and with the writings of the eccentric Marxist, George Thomson, whose books on Ancient Greece were published in German translation in East Germany in 1980. For those writing in this tradition, there is no doubt whatsoever that matriarchy was the primal form of social organisation and was forcibly suppressed throughout the Ancient World - for all that the majority of pre-historians now take a much more skeptical view of what Graves and Thomson portray as irrefutable truth.

But such dogmatism suits Christa Wolf's particular brand of feminism. From the composition of Kassandra in the early ' 80 s to the completion of Medea in the late ' 90 s, her insistence on the historical reality of a matriarchal age in a pre-literate Ancient World has elements about it of a religious conviction, which may well relate to her loss of faith in socialism as practiced in the former German Democratic Republic. In the lectures on the composition of Kassandra, she freely admits that her construction of a matriarchal Troy is tantamount to a 'model for a kind of Utopia' (Wolf 1983, p. 83). In this context, too, she draws from the dominance of female figures in the Minoan art of Ancient Crete the following conclusion:

Feminists, women committed to the women's movement, saw in the kingdoms of the Minoans communities to which they could attach their utopian longings at a time when their experience of the present and fear of the future had driven them into a corner. This all did once exist: the country in which women were free and placed on an equal footing with men. (Wolf 1983, p. 61)

If one considers Christa Wolf's career as an East German writer, then it is improbable that she could have become the literary darling of the regime with her early works, in fact have briefly been even a candidate for the Central Committee of the SED, without convincing others of the sincerity of her belief that socialism was being realised, rather than betrayed, by the regime that built the Berlin Wall. It is equally improbable that her faith in the regime and the dogmas it endlessly propagated could have wholly withstood such events as the expulsion of the critical, but still committed communist Wolf Biermann and annulment of his citizenship in 1976 and the attacks on her own works in the regime's literary periodicals, such as occurred in reviews of her novel about growing up in Nazi Germany in wartime. Her turning to themes in antiquity which, on the one hand assert the utopian values of a matriarchal age, while 
on the other showing its destruction and deformation by the rise of patriarchal rule and the discourses that accompany it, may thus be seen as filling a gap caused by disillusionment with a system which had rewarded her loyalty by insisting she should give up her intellectual independence and write closer to the party line.

She begins to conceive her remodeling of Medea two years after the end of the East German regime, and it comes as no surprise that her heroine is at home nowhere, neither in the discredited Colchis she has left behind her, not in the Corinth which is given to its own modes of celebrating its superiority as a culture and a state. Thus her novel becomes one long meditation on the theme of estrangement. Cast in the form of a plurality of voices, it clearly avoids the dramatic interaction of conflicting passions and ambitions that makes up the essence of Euripides' drama. Wolf's Medea does not so much contribute actively to the unfolding of the plot, as merely speak and be spoken about. While a dramatic framework would force her into acts of self-assertion and aggression, the many voices that speak about her in the monologues of Christa Wolf's text, without drawing any direct response from Medea herself, have the cumulative effect of reducing her to being predominantly the object of the discourses of others.

Christa Wolf is here grafting her novel onto that tradition of feminist argument which maintains that western thought has privileged subjectivity as a masculine attribute, whilst woman is accorded object-status. In this sense, Luce Irigaray had written:

It is beyond doubt the subjectivity denied to woman which ensures her constitution as an object: as an object of representation, of discourse, of desire. [...] The inarticulate devotion of the one party guarantees the self-satisfaction, the autonomy of the other for as long as there is no necessity to subject this dumbness to critical scrutiny a symptom - of historical repression. (Irigaray 1980, p. 169)

Such considerations could well have influenced the poverty of independent action on the part of Wolf's Medea. Far from attempting to take active revenge for the humiliating treatment accorded to her in Corinth, she limits herself to detecting and further inquiring into the dark secret of the sacrifice of Iphinoe upon which the reign of Creon is founded. It is not necessary for her to broadcast her discovery-it is sufficient that Agameda sees her following Queen Merope into the underground vaults where the skeleton of Iphinoe is preserved for the process to begin which will make her an outcast. As Leukon observes: 
And I understood that it was simply Medea's bad luck to have brought to light the buried truth which determines the life of our community and that we are unable to endure this. And that I can do nothing. (Wolf 1999, p. 160)

In the dystopian world of Corinth, it is sufficient for Medea to be the 'outsider who knows' to make her presence unendurable and to bring down on her both mobviolence and the sentence of banishment.

It is surely no coincidence that two of the epigraphs to chapters in Christa Wolf's novel are taken from the work by René Girard, first published in France in 1972 and translated into English in 1977 as Violence and the Sacred. To judge from her lectures on the composition of Kassandra, Wolf's acquaintance with Girard postdates the coming-down of the Berlin Wall, as the work from which she takes the epigraphs in her Medea is not listed among the sources for her earlier recasting of a Greek myth. Moreover, the German translation of Girard's book did not appear until 1992.

While Euripides' Medea gets only a passing mention in Girard's lengthy discussions of Ancient Greek tragedy, much that he says of the sacrificial process as a 'safety valve' for the violence always likely to turn his version of ancient or 'primitive' societies into anarchy seems to have been woven into Christa Wolf's recasting of the myth. Girard insists that 'the sacrificial process requires a certain degree of misunderstanding.' The human victim is not really to blame for the ills that afflict a given community, but the channeling of those aggressions, that might otherwise rend the fabric of society, into a divine imperative to put to death or expel one of their number neutralises forces which might become uncontrollable. As Girard puts it:

In a universe where the slightest dispute can lead to disaster [...] the rites of sacrifice serve to polarize the community's aggressive impulses and redirect them toward victims that may be actual or figurative, animate or inanimate, but that are incapable of propagating further vengeance. [...] The sacrificial process prevents the spread of violence by keeping vengeance in check. (Girard 1977, p. 18)

One variant on Euripides' plot introduced by Christa Wolf is the episode in which Medea is hunted through the streets of Corinth by a mob of citizens who have been influenced into blaming her for the plague which has broken out because corpses have been left to decay in buildings destroyed by an earthquake. Girard's theories seem especially relevant here, since Wolf's Medea - unlike Euripides' — cannot pose any real threat to her persecutors. Not only has she nothing to do with the earthquake and 
consequent plague, but Wolf's depriving her both of her passion for revenge and the supernatural powers that might enable her to carry it out, were she so inclined, make of her an ideal 'pharmakos' in Girard's sense:

The city of Athens prudently kept on hand a number of unfortunate souls, whom it maintained at public expense, for appointed times as well as in certain emergencies. Whenever some calamity threatened - plague, famine, foreign invasion, or internal dissension - there was always a pharmakos at the disposal of the community. [...] That is why the pharmakos was paraded about the city. He was used as a kind of sponge to sop up impurities, and afterward he was expelled from the community or killed in a ceremony that involved the entire populace. (Wolf 1999, p. 94-95)

Creon's Corinth fulfils all the conditions that make expedient the transformation of Medea into such a scapegoat. It is a corrupt regime, hence full of latent violence, and the rulers' failure to take preventative action to avert an outbreak of plague after the earthquake creates a mood of panic among the citizens. Medea has lost the status she originally held as Jason's wife by being expelled from the palace. She is a stranger with the aura of witchcraft about her. A campaign of defamation resurrects the calumny that she murdered Apsyrtos, her own brother, many years before. She thus becomes a suitable object on which the community can vent its spleen by formally putting her on trial and subjecting her to a sentence of banishment — without fearing a wave of retaliatory violence such as bursts forth in the versions of Euripides and Seneca. Her sons are later stoned to death as an extension of the same process. Christa Wolf's obvious borrowings from Girard have the effect of making the community rather than the individual the centre of violence.

This focus on communities as having their own psychopathologies and thus a corresponding need of therapy and healing links Wolf's reading of Girard with her personal experience of a united Germany. For the lack of moral distinction between Colchis and Corinth in the novel surely reflects her own dual disillusionment with the East German regime that was and with the emotional climate of a reunited Germany. In an interview which Petra Kammann recorded shortly after the novel appeared in 1996, Christa Wolf states:

I was surprised myself that I was becoming once more obsessed with a mythological theme, but in fact it was not so incongruous. I began trying to come to terms with the figure of Medea in the years 1990/91. At that time it had become apparent to me that our own culture, whenever it gets into a state of crisis, always relapses into the same patterns of behavior: to put people on the other side of imaginary borders, to make scapegoats of them, to cultivate images of 'the enemy' to the point of a pathological misapprehension of reality. [...] In the GDR, I had witnessed, at first hand, into what a wretched situation a state gets when it publicly stigmatizes larger and larger groups of its own citizens, thus losing more and more of its capacity to integrate. Today 
we are experiencing in the expanded Federal Republic the parallel phenomenon that larger and larger groups of people are simply becoming superfluous - for social, ethnic and other reasons. (Hochgeschurz 1998, p. 50)

Ironically, Christa Wolf's novel itself was to fall victim to such hostile simplifications as she here attributes to both societies. It was seen as a polemical statement in the wars of resentment between 'Ossis' and 'Wessis' once the euphoria of reunification had evaporated, as a 'textbook case of an East-West drama' (Hochgeschurz 1998, p. 118). The critic who produced this formulation in the influential newspaper Die Zeit, then went on to claim that Colchis is - for Christa Wolf - the land of matriarchy, whereas Corinth is the despised and patriarchal west. He then imputes to Wolf the claim 'that matriarchy (East Germany) is morally superior to patriarchy (West Germany)'. As the Italian critic, Anna Chiarloni, rightly points out, this is simply not borne out by the text of the novel (Hochgeschurz. 1998 p. 11) For Wolf is at pains to demonstrate a moral sameness between Colchis and Corinth: both emerge in her recasting of the myth as tyrannies based on the sacrifice of the innocent.

It is easy to see how Wolf's removal of Euripides' attributes of violence and power from the figure of Medea could be interpreted - in the context of the East-West polemics of the ' $90 \mathrm{~s}$ - as a general plea for the exculpation of East Germans in general and the author herself in particular by making them appear as well-meaning victims in a heartless, capitalistic Corinth as a model of united Germany. For the novel does indeed maintain: 'Corinth is obsessed with the desire for gold [...] And what shocked us [Colchians] most: the worth of a citizen of Corinth is measured by the amount of gold he possesses [...]' (Wolf 1999, p. 35).

There may indeed be in the novel a line of bleak and unforgiving criticism of the imperfections of the united Gemany of the ' $90 \mathrm{~s}$ - but the nostalgia of the Colchian refugees for a Colchis that never was is equally shown in terms that stop just short of contempt. The level on which the East-West question is alluded to is one of the more superficial strata of the text, but it was a convenient pretext for critics to dismiss Christs Wolf's portrayal of Medea as a naïve and cliché-ridden intervention in a debate neither side can meaningfully win. The centre of the novel's intentions and achievement lies elsewhere. 
The fact that Wolf freely admits that she began working on the figure of Medea from a conviction that Euripides' notorious heroine could not have murdered her own children and the shrill objections of reviewers of the novel to precisely this change in the plot have both tended to obscure the complexity of the figure she creates and of the processes she depicts in the novel (Hochgeschurz 1998, pp. 15, 41). While Wolf may have not abandoned the view of the matriarchy as a historical reality which she held in the early ' 80 s and owes to Graves and Thomson, her thinking has moved on from there, as her borrowings from Irigaray and Girard reveal.

But there is a more important debt to consider in her novel of 1996, namely to the critique of Western civilisation by Horkheimer and Adorno in their Dialectic of the Enlightenment. Their main achievement lies in showing the irrational myths created by the self-assured discourse of reason to disguise its own shortcomings and its intimate connections with social and political power. By arrogating to itself a sovereign impartiality, the discourse of reason leaves itself vulnerable to such selfdeceptions as resulted in the rise of Fascism in the $20^{\text {th }}$ century and Germany's consequent negation of all the values Enlightenment philosophy affirmed. In short, reason, as a public institution, mythicises itself in ways that blind it to the prejudices and destructive impulses that are still latent within it.

Thus the German critic, Ricarda Schmidt, writing in 1998, interprets the murder of Medea's children, in Wolf's version, by mob violence in terms borrowed from Horkheimer and Adorno: 'These children are victims of power in the modern sense, not human sacrifices in the mythological or historical tradition' (Schmidt 1998, p. 312). It is fair to say that Wolf makes this 'modern sense' credible by applying what she had gained from Girard. However, her portrayals of two societies whose powerstructures are based on the irrationality of the sacrifices of Apsyrtos and Iphinoe for political motives, which must be disguised within the various modes of each state's self-representation, is a direct application of ideas from the Dialectic of the Enlightenment.

Another critic, Friederike Mayer, basing her concluding argument on quotations from Horkheimer and Adorno, brings this aspect into sharper focus: 
For reason is merely a domesticated, superficial layer beneath which the 'bloodthirsty inner dimension' lies, and here are 'energies that are stronger than reason'. [...] The 'calculating reason' which governs life in Corinth, on the basis of which the Corinthians are intent on avoiding confronting what they are afraid of, which looks for scapegoats so that they do not have to acknowledge the horrors in their own past, permits 'the seeds of a new barbarism' to germinate and thrive. (Meyer 1997, p. 94)

In these terms, the cultural criticism implicit in Wolf's Medea is more fundamental and incisive than the trivial contrasting of an 'East that was' with a 'West that is' that was all some hostile German reviewers could see in her work. The point of the murders of the children in Wolf's version is not so much that Medea does not commit them herself, but that, having occurred as an incidence of collective violence born of fear - Corinth is still being laid waste by a plague - the guilt is attributed to her by a consensual lie. Then the lie, in turn, is institutionalised into an annual ritual which serves as the basis of a myth. In the terms of Horkheimer and Adorno, a myth within the context of instrumentalised reason is, by definition, opaque - a construct beneath whose surface those who accept it do not probe, because to do so would be to reveal the cracks in the edifice of reason itself.

By this process, it serves the purposes of the power-structure dominant in Corinthian society much better to transform the banished and harmless Medea into a mythical icon of the evil witch and unnatural, destructive mother than to inquire further into the real causes of the plague that unleashed - through fear - the collective violence that killed her children in the first place. To conduct such an enquiry would be to probe beneath the surface of Corinthian self-representation and risk discovering - as has Medea previously - the grisly secret at the base of Creon's continuing rule and the subterfuges which, as expounded by the cynical power-broker Akamas, are essential to its stability. That Medea's own father, Aietes, also shored up his power by resorting to similar means, and that it later becomes expedient in Corinth as well to defame Medea as the murderer in Colchis of her own brother Apsyrtos, demonstrates conclusively that Wolf's prime concern is not any kind of partisan statement from an East German viewpoint about the shortcomings of society in the united Germany, but rather to revisit issues first raised by Horkheimer and Adorno in the wake of the defeat of Nazism in terms that relate to contemporary European society as a whole. 
It is also a tribute to Wolf's artistry that she refrains from idealising the figure of Medea herself. Given the somewhat unsophisticated feminism that underlies her Kassandra and her continued adherence to visions of a primal matriarchy in the Ancient Mediterranean world that remains more an article of faith than anything archaeology has confirmed, the way was surely open - given the revisions in Euripides' plot for which she had opted - to portray a Medea who was at least at ease with herself and could look down on the machinations of patriarchal society with triumphal disdain.

But Christa Wolf has stopped short of doing this, and presents instead - as shown by the passage quoted above with which the voice of Medea ends the novel — a figure who is in virtually all phases of her life in a state of alienation. She does not disown her loyalties to her own home through an irresistible love for Jason, as some versions of the myth would have it, but because she finds the rule of her father Aietes unworthy of her loyalty and Jason offers a possibility of escape. Her loss of status in Corinth, when Creon has her expelled from the palace as a preparation to making Jason the husband of his daughter Glauké, does not outrage her, since her social position means nothing to her and Jason has merely used her as a sexual objectsomething he continues to do even after she has become a public outcast.

While Christa Wolf does not acknowledge any explicit debt to the writings of Julia Kristeva, there is much in her Medea that is reminiscent of what Kristeva writes of the-for her_ primal social myth of the Danaids in her book Strangers to Ourselves:

A fact that one cannot ignore: the first strangers that appear at the beginning of our culture are women - the Danaids. [...] Alienness - the political expression of force-seems to lie at the basis of the elementary forms of civilisation, to be its necessary obverse [...] Furthermore, the alienness of the Danaids also raises the problem of the rivalry of the sexes in their extramarital connections, in love and sexual relationships. For what 'relationship' exists between the 'people' or 'race' of men and the 'people' or 'race' of women? (Kristeva 1990, pp. 51-5)

The Danaids were the fifty daughters of the mythical Greek ancestor-king Danaus who fled from Libya to Greece so that they would not be forced to marry the fifty sons of Danaus' brother, Aegyptus. These catch up with Danaus and his daughters in Argos and a mass-marriage is arranged. The Danaids all murder their bridegrooms on their wedding-night, with one exception, so as to avoid being murdered themselves. Danaus then sets about marrying off his daughters one by one to locals, no easy task 
because of their reputation as murderesses. It is thus a myth about the problematic assimilation of (female) refugees by marriage (Graves 1961, pp. 200-203).

Something of the radical estrangement between women in general and their-male dominated - social context, and also between women and their individual male partners, that pervades Kristeva's book seems to have been incorporated into Christa Wolf's reinvention of the figure of Medea. Estranged from her native Colchis, she finds no sense of belongingness in Corinth - even before her discovery of the remains of the sacrificed daughter of Creon, Iphinoe, makes her a voluntary outcast long before she is banished.

Since the late $18^{\text {th }}$ century, the figure of Medea has presented a severe challenge to male writers, fascinated by the myth, but at a loss as to how to deal with a heroine who murders her own children. Thus Goethe's contemporary, Friedrich Maximilian Klinger, wrote two dramas around the figure, Medea in Corinth (1787) and Medea in the Caucasus (1791), the second with the intention of exorcising the destructive elements in her character by having her undergo a rehabilitation in the sense of Enlightenment didacticism. Repenting of her violent past life and eager to follow the dictates of reason, she devotes herself utterly to bringing civilised values to a 'primitive', savage community in the Caucasus mountains.

The major Austrian dramatist of the early $19^{\text {th }}$ century, Franz Grillparzer, made of Euripides' sparse tragedy a whole trilogy of plays, mainly in order to make Medea's murder of her children intelligible to contemporary audiences in terms of the stereotypes of female psychology then dominant. Whereas in Euripides' version the children say nothing on stage, Grillparzer makes them articulate so as to show them turning away from Medea and towards Jason's new bride. The maternal bond is deliberately weakened in this way by the children's rejection of their natural mother. Thus their killing is more an act of despair by a woman abandoned by all than one of revenge by a figure of power.

Not surprisingly, it appeared to many German reviewers that Wolf's radical alterations to the traditional plot, which remove precisely those elements from it which post-Enlightenment European society finds hardest to accept, were essentially 
cosmetic and motivated by a desire to 'save' Medea for modern feminism, whilst scarifying the prevailing attitudes of a united Germany on the side. In this sense, her figure has been read as a kind of 'Medea for popular feminism.' Certainly, an element of exculpation is present. But the main appeal of the novel is to call for a fresh examination of the basis of the recently united Germanies by illustrating how myths arise which divide societies into hostile factions by blurring the unpalatable truths of the past. It is thus a fresh call to go beyond the superficialities of the social antagonisms in the reunited Germany in the late '90s, to continue the task envisaged by Horkheimer and Adorno in 1944:

The point is rather that the Enlightenment must examine itself, if men are not to be wholly betrayed. The task to be accomplished is not the conservation of the past, but the redemption of the hopes of the past. Today, however, the past is preserved as the destruction of the past. (Adorno \& Horkheimer 1989, p. xv)

It is undeniable that, in present-day Germany, the political decision of the U.S. to pour aid into West Germany in the aftermath of 1945, so that it could become rapidly selfsufficient in economic terms and no longer be a burden, has become converted into an aura of moral superiority on the part of the 'Wessis' towards their fellow Germans in the East. 'Ossis' have had the painful experience of the devaluation of their personal pasts by virtue of the fact that they did not grow up in the democracy that the Marshall Plan also made possible in the West, but under the political conditions imposed by the Soviet Union's transformation of its zone of occupation into a satellite state in its own image. Turning the consequences of international power-plays in the wake of the defeat of Hitler into a myth of moral and cultural superiority a halfcentury later is the kind of process upon which Wolf's Medea seeks to open a critical perspective.

She does this, firstly, by subjecting the myth to an 'alienation effect' in Brecht's sense: her Medea is emphatically not the Medea her readers are expecting. This opens the way to a critical re-examination of the assumptions latent in Euripides' version. Secondly, she refrains from a simple reversal of the myth in emotional terms and, instead, strands her heroine in a situation in which insight and exculpation do not produce a freeing of the figure from the alienation that besets her in all phases of her life. But, if the European Enlightenment is not to betray itself once more, it is necessary to remain aware that society's dealings with its own past are always prone 
to lapse into processes of myth-making that are both convenient for the powerful majorities and distortions of the truths that underlie such power. This is what Christa Wolf signals to her readers in her preface and what her novel subsequently bears out:

Posing the wrong questions to her puts the figure that wishes to emerge from the darkness of misunderstanding at a loss to answer. We must warn her. Our misunderstanding forms a closed system - nothing can refute it. Or else we have to dare to penetrate into the inmost recesses of our misapprehension and self-misapprehension, simply tread this path, together, in single file, with the roar of collapsing walls in our ears. Beside us - so may we hope - goes the figure with the magic name, the figure in which the ages encounter one another. In which our own age encounters itself - a painful process. The savage woman. (Wolf 1999, p. 10)

\section{Reference List}

Adorno, Theodor \& Horkheimer, Max 1989, Dialectic of Enlightenment, trans. John Cumming, new edn, Verso 1989, London/New York. Originally published in 1944 as Dialektik der Aufklärung, Social Studies Association, New York.

Girard, René 1977, Violence and the sacred, trans. Patrick Gregory, The Johns

Hopkins University Press Baltimore and London. Originally published in 1972 as La violence et le sacré, Paris.

Graves, Robert 1958, Greek Myths, Cassel \& Campany, London.

Graves, Robert 1961, The white Goddess, Faber and Faber, London:

Gutjahr, Ortrud 1988, 'Mythos nach der Wiedervereinigung. Zu Christa Wolfs Medea. Stimmen und Botho Strauss' Ithaka' in Antikquitates Renatae. Deutsche und französische Beiträge zur Wirkung der Antike in der europäischen Literatur. Festschrift fur Renate Böschenstein zum 65.

Geburtstag, eds Verena Ehrich-Haefeli, Hans-Jürgen Schrade \& Martin Stern, Königshausen \& Neumann, Würzburg, pp. 345-360.

Hochgeschurz, Marianne (ed.) 1998, Christa Wolfs Medea. Voraussetzungen zu einem Text. Mythos und Bild, Gerhard Wolf Janus press, Berlin.

Irigaray, Luce 1980, Speculum. Spiegel des anderen Geschlechts, Frankfurt a.M.

Kaminski, Nicola 1997, 'Sommerstueck - Was bleibt-Medea. Stimmen. Wende-

Seismographen bei Christa Wolf' in Zwei Wendezeiten. Blicke auf die deutsche Literatur 1945 und 1989, eds Walter Erhart \& Dirk Niefanger, Niemeyer, Tübingen, p. 115-139.

Krätzer, Jürgen 1997, 'Das Kassandra-Syndrom. Medea Stimmen und Gegen-

Stimmen: Christa Wolfs Medea im Spiegel der Literaturkritik' in Die Horen.

Zeitschriften fur Literatur, Kunst und Kritik, no. 2, pp.48-60.

Kristeva, Julia 1990, Fremde sind wir uns selbst, trans. by Xenia Rajewsky, Suhrkamp, Frankfurt a. M. Originally published in 1988 as Estrangers à nousmêmes, Paris.

Mayer, Friederike 1997, 'Potenzierte Fremdheit: Medea - die wilde Frau. Betrachtungen zu Christa Wolfs Roman Medea. Stimmen' in Literatur für Leser, no. 1, pp. 85-94.

Paulys Real-Enzyclopädie der classischen Alöteertumswissenschaft, Neue Bearbeitung 1934, Metzler, Stuttgart, Bd. 15, 1.

Rupp, Gerhard 1999, 'Weibliches Schreiben als Mythoskritik. Christa Wolfs Roman Medea. Stimmen' in Klassiker der deutschen Literatur. Epochen-Signaturen 
von der Aufklarung bis zur Gegenwart, ed. Gerhard Rupp, Königshausen \&Neumann, Wurzburg.

Schmidt, Ricarda 1998, 'Das ausgeschlossene Andere der abendländischen Zivilisation. Zu Christa Wolfs Medea', Amsterdamer Beiträge zur neueren Germanistik, vol. 43, pp. 297-315.

Shafi, Monika 1997, "Falsch leiden sollte es das auch geben". Konfliktstrukturen in Christa Wolfs Roman Medea' in Colloquia Germanica. Internationale Zeitschrift für Germanistik (30), pp. 375-385.

Wolf, Christa 1999, Medea. Stimmen, dtv, München. First published 1996.

Wolf, Christa 1983, Voraussetzungen einer Erzählung: Kassandra. Frankfurter Poetik-Vorlesungen, Luchterhand, Darmstadt und Neuwied. 